\title{
Shenyang Rail Transit's Investment and Financing Management Mode Selection
}

\author{
Qin Yi \\ School of management \\ Shenyang university of technology \\ Shenyang, China \\ e-mail: qiny_cr@sut.edu.cn
}

\author{
Wang Renxiang \\ School of economics \\ Wuhan university of technology \\ Wuhan, China \\ e-mail: Wangrx@whut.edu.cn
}

\begin{abstract}
As quasi-public goods, urban rail transit's investment and financing management mode selection determines its operation form, which also determines the operation efficiency and effectiveness of the rail transit. While, the different lines in different regions have different characteristics, which have different requirements for rail transit's investment and financing management mode selection. In this paper, by synthesizing the existing studies, which forms matching index system and use fuzzy comprehensive evaluation method, Shenyang Rail Transit's investment and financing management mode has been studied.
\end{abstract}

Keywords-Rail transit; investment and financing management model; matching

\section{INTRODUCTION}

Urban rail transit as a quasi-public goods, on the one hand with strong externalities, its social benefits far outweigh the economic benefits of the project itself, which means it is reasonable for government to take part of the construction funds; on the other hand, the urban rail transit project has a certain quasi-operational, which does not necessarily mean that all construction funds should be provided by the government. The things that need to be done by government are creating a series of institution and policy systems to attract social capital and it will create a secure environment for investment. Finding a equilibrium point between the investor's benefit protection and the maximizing of the social welfare benefits has become one of the key factors of the project's investment and financing management mode selection[1] However, due to different lines in different regions have different construction purpose and function requirements, so investment and financing management model selection should be constrained by these qualities and also should comply with the requirements of quasi-public goods, which requires a matching model to select [2].

\section{THE ANALYSIS OF URBAN RAIL TRANSIT}

\section{INVESTMENT AND FINANCING MANAGEMENT MODEL}

Investment and financing management system of urban rail transit is related to its organization and operation forms. Currently, it is mainly in the form of direct government management, entrusted operation, integration management and commercial operation models, which has formed a variety of investment management modes. The general studies using the research result of
Wang Hao (2010) that divided the existing investment management model into five categories, namely the integrated monopoly of government-led investment management mode, government-led professional management mode, transparent supervision of an integrated monopoly model, the coexistence of competition and government subsidies mode and moderately effective competition integrative mode [3].

\section{A. The model of government-led integrated monopoly}

Its essence is that the government is responsible for all the investment and operation subsidies of the construction and appoints an institution responsible for the investment, construction and operation. Beijing Metro Group adopted this model before its spin-off. Currently, the majority of rail transits in western developed countries adopt this model. Operation in the construction of urban rail transit investment in this model is generally directed by the leadership of the local government. The departments in government are respectively responsible for planning, investment, subsidies and supervision matters [4]. At the main time, the government funded for the establishment of a full-time subway company and set up different departments responsible for internal specific issues in different lines, such as financing, construction and operations. Solving the shortage of investment through loans and subsiding all the operating losses by government.

Due to the less relevant stakeholders, this model gets the advantage of the simple relationship, meanwhile government's decisions, implementation and coordination efficiency becomes higher. The investment subject of this mode is single, which leads to increased pressure on government finances and it is easy to cause the shortage of funds; the burden of higher operating costs need to be borne by government subsidy [5]. In addition, due to the inefficiency of government's programs exist $\mathrm{X}$, soft budget constraints are formed, resulting in low efficiency in the use of the funds. Based on uniqueness of the subjects in form and diversity of the subjects in specific operation, it will easily lead to the inconsistency among rights, responsibilities and profits and decrease the efficiency of operation. 


\section{B. Government-led professional management model}

It mainly refers to all the investment and operation subsidies for the construction are taken charge of the government, at the same time, specifying another company to be responsible for the completion of the investment, construction and operation, etc. There are many implementation forms for this model, typical example like Beijing's Three Separation (investment, construction and operation) and Four Separations for Shanghai (investment, construction, operation and supervision) and so on [6].

We take the three separations as example to elaborate. Under this mode, urban rail transit investment and construction are carried out under the direct leadership of the government, various government departments are responsible for planning, investment, subsidies and supervision matters, while the government funded the establishment of urban rail transit's investment company, construction company and operation company, which are respectively responsible for the financing of rail transportation, construction and operation. Lack of investment partly are settled through loans and the government fully subsidies for operating losses [7]. The model breaks the traditional integrated model, which introduces market-oriented model in different operational aspects and forms competition at different stages. It is conducive to achieve information disclosure in three stages, and thus facilitates the formation of rights, responsibilities and benefits and makes them restrain each other, which enhances decision-making scientific degree.

\section{Integrated Monopoly under Transparent Supervision Model}

As mentioned earlier, many countries and regions use government investing directly and integrated operation mode, but the difference for our country is its establishment of a clear regulatory system, which make the security, quality of service, the commercial running principle and costs suffer the strict constraints. The operation of this model in different countries and regions are largely different, the typical case is Hong Kong, China.

Take Hong Kong MTR Corporation for example, the company's largest shareholder is the Hong Kong SAR Government, but the company entirely invests and runs on according to commercial principles. The corporation plans to propose appropriate property when planning new lines, while developing the property in the same time with subway construction. Financing the funds according to property that is needed to sell and use the income of the property to support and subsidies for the rail transport operations, which achieves the real external benefits achieve internalization [8].

But the implementation of this approach needs for strict conditions, which is to reduce the monopoly that brings inefficiencies through an open and transparent regulatory system and social oversight environment.

\section{Competition and government subsidies coexistence model}

A typical form of this model is the PPP. Under this mode, for the public service needed by the community, the government no longer directly invest in public projects, but to encourage enterprises to invest in and set up (or enterprise sets up a joint venture with the government) projects and the provide with the public services, then the government will purchase after considering the required service quality and quantity together. It can be seen that not only the competitions are introduced. At the same time, the government also gives the urban rail transit construction subsidies. This model has front or rear compensation modes [9].

Under the previous compensation model, investment and construction of urban rail transit is generally carried out under the leadership of local government. The government departments are responsible for planning, investment, subsidies and regulatory content, while the government set up a special investment and financing platform and the companies responsible for the specific market-oriented operation. Government determines the construction of rail transit planning, under the assistance of the investment and financing platform, in accordance with the actual situation to implement different marketization plans, which is basically the government partly invests in the network, while, the run part gives the market, and the government supervise the project company[10]. The advantage of this model is that the investment project is divided into two parts, one is referred to some government investment in public welfare, and the other part is the ability to continue to introduce a variety of social capital for-profit part, which can achieve the expansion of funding sources to meet the purpose. In premise of each main subject can be mutual restraint, it is more conducive to raising the capital utilization efficiency and lowering the investment risk [11].

In the latter compensation mode, based on the capital system, the government departments and social capital builds up the joint venture project company, which is responsible for the investment, construction and operation. The government needs to check and ratify operating costs and future income of the project company previously, and the government will give appropriate subsidies to the loss arising from the operation process of project [12]. The companies need to transfer all the assets of the project after the completion of the concession period free of charge to the government.

\section{E. Model of Moderately Effective Competition Integration}

This pattern is an appropriate number of present qualified investors, who get certain set of capacities, like investment, construction, operation and management in the market, choosing the most appropriate investment operators through competition, granting franchise rights, building sustainable and reasonable subsidies and incentives institution. Then according to different evaluation criteria, the government gives reasonable subsidies and supports.

\section{Evaluation MOdEL AND EVALUATION INDEX SYSTEM CONSTRUCTION}

The process of mode selection is essentially a multimode environment adaptability evaluation process. This paper chooses fuzzy comprehensive evaluation method to evaluate and implements the process of selection. 
A. Determine the evaluation factors set $F$ and comments set $E$

Factors set $\mathrm{F}$ is a set of evaluation index, $F=\left\{f_{i}\right\}=\left\{f_{1}, f_{2}, \cdots, f_{n}\right\}, i=1,2, \cdots n$. Comments set $\mathrm{E}$ is a collection of evaluation level, $E=\left\{e_{j}\right\}=\left\{e_{1}, e_{2}, \cdots, e_{m}\right\}, j=1,2, \cdots, m$, such as $\mathrm{E}=\{$ excellent, good, fair, poor $\}$.

\section{B. Count the univariate evaluation subordinated degree} vector, form subordinated degree matrix $R$

Subordinated degree $r_{i j}$ refers to the likelihood of the evaluation subject making an evaluation of $\mathrm{Ej}$ in the $\mathrm{Fi}$ indicators. Subordinated degree vector $\mathrm{Ri}=\{$ ri1, ri2, ..., $\operatorname{rim}\}, \mathrm{i}=1,2, \ldots, \mathrm{n}$, subordinated degree vector $\mathrm{R}=\{\mathrm{R} 1$, $\mathrm{R} 2, \ldots, \mathrm{Rn}\}^{\mathrm{T}}$.

\section{The analytic hierarchy process to determine the weight vector $W F$}

Determining the ratio scale of the index is to classify the comparison results of two-factor, such as compare index 1 to index 2 same, strong, stronger, very strong, strongest $\}$, and assign it $\{1,3,5,7\}$, so that experts score all the indicators to make the pairwise comparison and get the judgment matrix W. Wherein, $\omega_{x y}, x=1,2, \cdots i$, $y=1,2, \cdots i$, and $\omega_{x y}>0, \omega_{x y}=\frac{1}{\omega_{x y}}, \omega_{x y}=1(i=j) ;$ and then use the normalization processing to deal with the judgment matrix, which obtain the weight vectors $W_{F}=\left(W_{i}^{0}\right)$, wherein, $W_{x}^{0}=\frac{W_{x}}{\sum W_{x}} \quad W_{x}=\left(\prod_{y=1}^{i} \omega_{x y}\right)^{\frac{1}{n}}$. Finally, give the consistency checking, find $\lambda_{\max } \approx \frac{1}{i} \sum_{x=1}^{i} \frac{(A W)_{x}}{W_{x}}=\frac{1}{i} \sum_{x=1}^{i} \frac{\sum_{y=1}^{i} \omega_{x y} W_{j}}{W_{x}}$ and consistency index $C . I .=\frac{\lambda_{\max }-i}{i-1}$. For C.I, the smaller it is, the consistency result is better.

\section{Determine the numerical result vector $W^{\prime} E$ of the comment set}

That means to determine the score that corresponds to each evaluation phrase.

\section{E. Calculate of the comprehensive subordinated degree} vector $S$ and overall score $u$

Comprehensive subordinated degree vector $S=W_{F} R$, $\mathrm{u}=\mathrm{W}^{\prime}{ }_{\mathrm{E}} \mathrm{S}^{\mathrm{T}}$

According to the synthesis of relevant references and the actual situation of Shenyang, the index system can be constructed as follows, detailed in Table 1.

TABLE I. ADAPTABILITY INDEX EVALUATION SYSTEM

\begin{tabular}{|c|c|c|c|}
\hline \multirow{2}{*}{$\begin{array}{l}\text { Target } \\
\text { Layer } \\
\text { A }\end{array}$} & \multirow{2}{*}{$\begin{array}{l}\text { Secondary } \\
\text { Index } \\
\text { B }\end{array}$} & \multicolumn{2}{|r|}{ Factor Layer C } \\
\hline & & Index & Note \\
\hline \multirow{13}{*}{$\begin{array}{c}\text { The } \\
\text { influencing } \\
\text { factors of } \\
\text { Rail } \\
\text { Transit's } \\
\text { investment } \\
\text { and } \\
\text { financing } \\
\text { management } \\
\text { mode } \\
\text { selection }\end{array}$} & \multirow[b]{2}{*}{$\begin{array}{l}\text { Political Factors } \\
\qquad(\text { B1) }\end{array}$} & $\begin{array}{c}\text { Macroeconomic } \\
\text { Management Capacity (C1) }\end{array}$ & $\begin{array}{l}\text { The national regulates the investment and financing economic } \\
\text { activity, which influences on the infrastructure construction. }\end{array}$ \\
\hline & & $\begin{array}{l}\text { the Degree of Political } \\
\text { Stability (C2) }\end{array}$ & $\begin{array}{c}\text { It refers that due to the war, regime change, regime change, related } \\
\text { investment and financing policy change, project capital damaged are } \\
\text { led, or the injecting capital or assets of the investors cannot be } \\
\text { expectedly achieved }\end{array}$ \\
\hline & \multirow{2}{*}{$\begin{array}{l}\text { Economic factors } \\
\text { (B2) }\end{array}$} & $\begin{array}{l}\text { the Maturity Level of the } \\
\text { Capital Markets (C3) }\end{array}$ & $\begin{array}{c}\text { The overall environment of the capital market in the rail transit } \\
\text { construction and operation of the process }\end{array}$ \\
\hline & & $\begin{array}{l}\text { the Influence of Interest rate } \\
\qquad \text { (C4) }\end{array}$ & $\begin{array}{l}\text { In rail transportation projects, it generally involves domestic and } \\
\text { international changes of investment and financing interest rates and } \\
\text { exchange rates lead to the changes of the assets value }\end{array}$ \\
\hline & \multirow{2}{*}{$\begin{array}{l}\text { Legal factors } \\
\quad(\text { B3) }\end{array}$} & $\begin{array}{l}\text { the Maturity Level of } \\
\text { Investment and Financing's } \\
\text { Law(C5) }\end{array}$ & $\begin{array}{l}\text { Whether the investment and financing laws are sound, whether there } \\
\text { are the legal norms of private equity capital and the state capital in } \\
\text { infrastructure investment and financing, and whether there are } \\
\text { relevant laws to solve the disputes and arbitration results. }\end{array}$ \\
\hline & & Default risk (C6) & $\begin{array}{l}\text { Project participants violate of the contract, and cannot continue to } \\
\text { fulfill the relevant obligations financing, which results in the project } \\
\text { cannot proceed smoothly. }\end{array}$ \\
\hline & \multirow{3}{*}{$\begin{array}{l}\text { Construction } \\
\text { factors }(B 4)\end{array}$} & Mode Selection (C7) & $\begin{array}{l}\text { Whether there is a sustainable profit model, and whether they have } \\
\text { the appropriate profitability }\end{array}$ \\
\hline & & Project Funds (C8) & $\begin{array}{c}\text { Whether the money can be paid on time during the construction } \\
\text { process and whether the engineering costs are excessive. }\end{array}$ \\
\hline & & Construction Period (C9) & $\begin{array}{l}\text { Whether the project can be implemented according to a } \\
\text { predetermined schedule, which may lead to extended duration. }\end{array}$ \\
\hline & \multirow{3}{*}{$\begin{array}{l}\text { Operational } \\
\text { factors }(\text { B5) }\end{array}$} & Operating Conditions (C10) & $\begin{array}{l}\text { Whether the energy to maintain its operation after the rail transit } \\
\text { project's completion are in place, and whether the device is good. }\end{array}$ \\
\hline & & Management (C11) & The management level of rail transit project operating company \\
\hline & & $\begin{array}{l}\text { Organizational Structure } \\
\qquad(\mathrm{C} 12)\end{array}$ & $\begin{array}{l}\text { Reduce the barriers to entry caused by economic technical } \\
\text { characteristics }\end{array}$ \\
\hline & $\begin{array}{l}\text { Natural factors } \\
\quad(\text { B6) }\end{array}$ & Natural Disaster (C13) & $\begin{array}{l}\text { Unforeseen impact of natural disasters such as floods, earthquakes, } \\
\text { typhoons, plague may affect project }\end{array}$ \\
\hline
\end{tabular}




\section{SHENYANG RAIL TRANSIT'S INVESTMENT AND FINANCING MANAGEMENT MODE EVALUATION}

According to the actual situation of Shenyang, we set four basic modes, namely Mode 1 government investment + debt financing, Mode 2 government investment + equity financing + debt financing; Model 3 government investment + bond financing + project financing; Mode 4 government investment + debt financing + project financing.

Constructing evaluation matrix for each evaluation index using AHP, and then have to settle the weight, take to secondary weights for example, detailed in Table 2 .

TABLE II. EVALUATION MATRIX OF SECONDARY EVALUATION INDEX

\begin{tabular}{c|c|c|c|c|c|c}
\hline & Politic & Economy & Law & Construction & Operation & Index \\
\hline Politic & 1 & $1 / 2$ & 1 & $1 / 4$ & $1 / 5$ & 0.077 \\
\hline Economy & 2 & 1 & 2 & $1 / 2$ & $1 / 3$ & 0.148 \\
\hline Law & 1 & $1 / 2$ & 1 & $1 / 4$ & $1 / 5$ & 0.077 \\
\hline Construction & 4 & 2 & 4 & 1 & 1 & 0.320 \\
\hline Operation & 5 & 3 & 5 & 1 & 1 & 0.379 \\
\hline
\end{tabular}

Then using the method of remark set to carry out pattern matching and adopt transforming triangular fuzzy numbers into numerical manner calculated approach to measure the results, with the example of local government owning and local government business model, which get the budget results shown in Table 3 .

TABLE III. LOCAL GOVERNMENT OWNING AND LOCAL GOVERNMENT BUSINESS MODEL

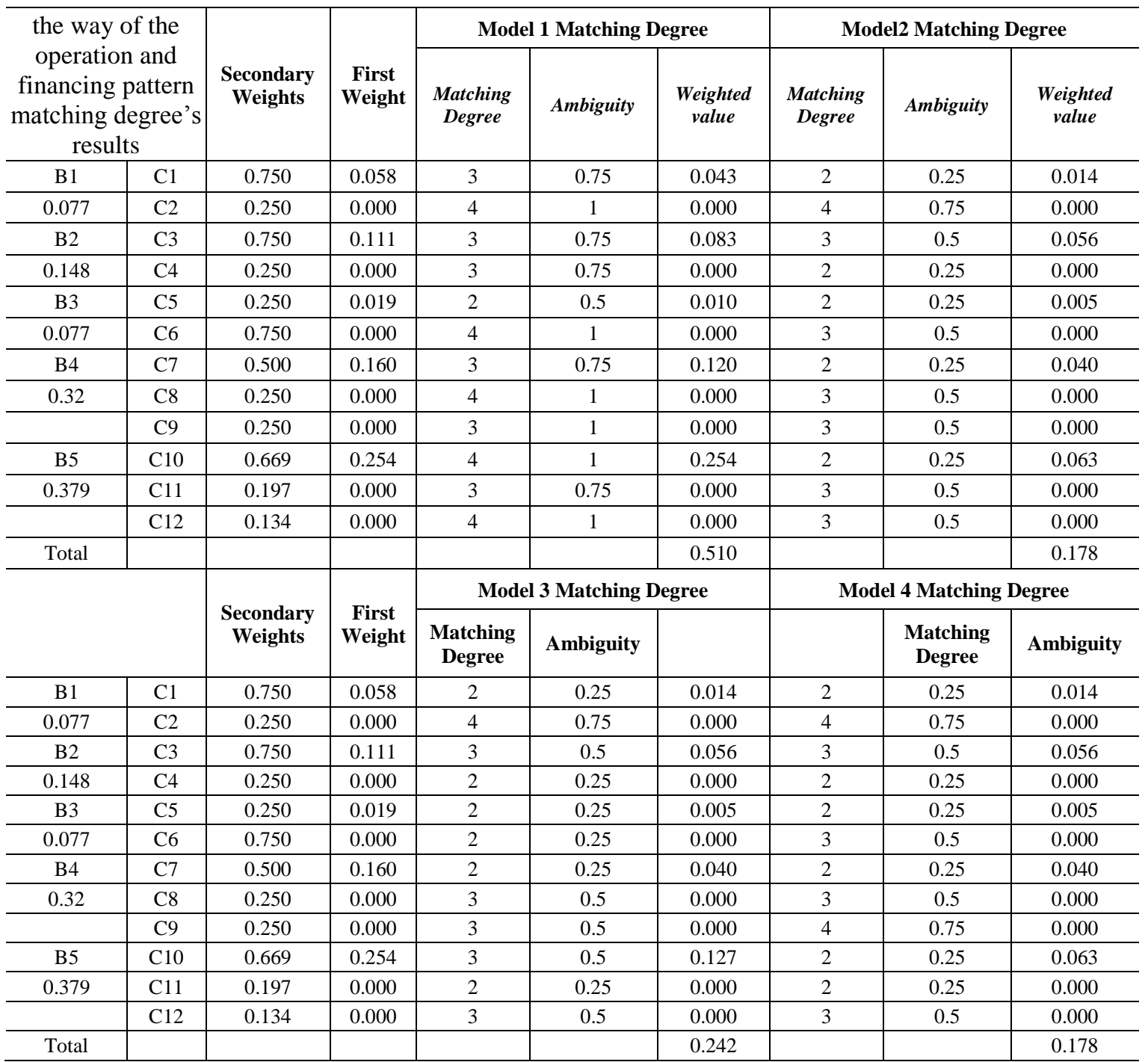


The fuzzy comprehensive evaluation method is adopted, which gets the order of the metro project funds based on the characteristics of its operation. Selection schemes in different operating mode: If use local government owning and local government business mode, it is the investment stage + financing scheme for government investment in operation stage + debt financing. If use local governments to cooperate with all company business model, it is investment stage + financing scheme for government investment in operation stage + bond financing + project financing.

\section{CONCLUSION}

Currently, there are five management models of Urban rail transit investment and financing, namely governmentled integrated monopoly investment and management model, government-led professional management model, and integrated monopoly under transparent supervision model, competition and government subsidies coexistence model and model of moderately effective competition integration. In this paper, comprehensive evaluation method is adopted. And it synthesizes the existing study to form matching system, which concludes that Shenyang rail transit investment and financing management model should select based on different lines and business objectives of the program.

\section{REFERENCES}

[1] Beaver, The rail promotes the development, constructs the integrated traffic system, word railway, 2005, pp. 271-350.
[2] Sock-yong phang. Urban mass traban mass teansit ppps: Survey and risk assessment of recent strategies. Transport policy, 2007, pp. 57-64.

[3] J. J. Buckley, T. Feuring, Y. Hayashi. Solving fuzzy problems in operations research: inventory control. Soft Computing, 2002, pp. 123-131.

[4] Yasushi H, Frank P, Jay R. Institutional affiliation and the role of venture capital evidence from initial public offering in Japan. Pacific-Basin,2000, pp. 231-243.

[5] Michael Gannon and Shawn Neidorf. Larger Ventrue capital Funds Spawn Bigger Deals as US Boom Continues. European Venture Capital Journal, 1999, pp. 341-349.

[6] Jugren Ronald K. Nvaigation and intelligent transportation systems, Society of Automotive Engineer, 1998, pp. 94-105.

[7] Sungmin Yun, Seung Heon Han, Hyoungkwan Kim, Jong Ho Ock. Capital structure optimization for build-operate-transfer (BOT) projects using a stochastic and multi-objective approach. Can. J. Civ. Eng. Vol. 74, Dec. 2009, pp. 777-790.

[8] Veronika Sabolova, Libena Tetrevova. Alternative forms of financing PPP projects. Business and management, 2010, pp. 176185.

[9] Jen-Jia Lin, Chi-Hau Hwang. Analysis of Property Prices before and after the opening of the Taipei subway system. The Annals of Regional Science, 2004, pp. 687-704.

[10] James W. Tvancs, Lilliam. Lindsay. The Management and Contro Quality. Cincinnati: Sout-Weatern Publishing, 2002, pp. 110-132.

[11] Lieb R, Randall H.CEO perspectives on the current status and future prospects of the third Party logistics industry in the United States. Transportation logistics, 1996, pp. 51-66.

[12] D, M. Lambert, A. E. Margaret, T. G. John. Building Successful Logistics Partnerships. Journal of Business Logistics, 1999, pp. $165-181$. 